
Brasileira 36: 353-356. DOI - http://dx.doi.org/10.1590/S0102-053620180311

\title{
Effect of aqueous neem seed extract via irrigation on larvae of Liriomyza sativae in melon crop
}

\author{
Ewerton M Costa ${ }^{1}$; Francisco EL Silva ${ }^{2}$; Elton L Araujo ${ }^{2}$ \\ ${ }^{1}$ Universidade Federal de Campina Grande (UFCG), Pombal-PB, Brazil; ewertonmarinho10@hotmail.com; ${ }^{2}$ Universidade Federal Rural \\ do Semi-Árido (UFERSA), Mossoró-RN, Brazil; edivino_ufersa@hotmail.com; elton@ufersa.edu.br
}

\begin{abstract}
The leafminer [Liriomyza sativae (Diptera: Agromyzidae)] is one of the main pests of melon crop (Cucumis melo) in the states of Rio Grande do Norte and Ceará. Thus, adopting strategies to control this destructive insect is essential. The aim of this study was to evaluate the effect of aqueous neem seed extract, applied to soil via irrigation, on leafminer larvae, in the melon crop. An experiment was conducted in greenhouse, in completely randomized design, consisting of five treatments (four doses of aqueous neem seed extract: $1 ; 3 ; 5$ and $10 \mathrm{~g} / 100 \mathrm{~mL}$ ) and the control consisting only of distilled water and 10 replicates (melon plants). The treatments were applied in a single dose, via soil irrigation. In the first stage of the evaluation, 24 hours after application, the number of dead larvae per plant was counted. In the second step, pupal mortality was recorded. The total mortality was also calculated considering the number of larvae and the number of emerged adults. We verified that, increasing the concentration of aqueous neem seed extract, an increase in the larval and pupal mortality of the leafminer in melon crop was noticed. The concentration $10 \mathrm{~g} / 100 \mathrm{~mL}$ presented the best results, resulting in $36.4 \%$ of larval mortality, $96.5 \%$ of pupal mortality and $96.8 \%$ of total mortality.
\end{abstract}

Keywords: Cucumis melo, Azadirachta indica, leafminer, integrated pest management.

\section{RESUMO}

Efeito de extrato aquoso de sementes de nim, via irrigação, sobre larvas de Liriomyza sativae em meloeiro

A mosca minadora [Liriomyza sativae (Diptera: Agromyzidae)] é uma das principais pragas do meloeiro (Cucumis melo) nos estados do Rio Grande do Norte e Ceará, o que torna imprescindível a adoção de estratégias de controle dessa praga. Nesse trabalho foi avaliado o efeito do extrato aquoso de sementes de nim, aplicado via irrigação no solo, sobre larvas da mosca minadora, em meloeiro. $\mathrm{O}$ experimento foi conduzido em casa de vegetação em delineamento inteiramente casualizado, composto por cinco tratamentos (quatro doses do extrato aquoso de sementes de nim: 1; 3; 5 e $10 \mathrm{~g} / 100 \mathrm{~mL}$ além do tratamento testemunha consistindo de água destilada) e 10 repetições (plantas de meloeiro). Os tratamentos foram aplicados em dose única, via irrigação no solo. Na primeira etapa da avaliação, realizada 24 horas após a aplicação dos tratamentos, contabilizou-se o número de larvas mortas por planta. Na segunda etapa foi registrada a mortalidade pupal e calculada a mortalidade total, considerando o número de larvas e número de adultos emergidos. O aumento da dose do extrato aquoso de sementes de nim proporcionou aumento da mortalidade larval e pupal da mosca minadora em meloeiro. A dose de $10 \mathrm{~g} / 100 \mathrm{~mL}$ apresentou os melhores resultados, ocasionando $36,4 \%$ de mortalidade larval, $96,5 \%$ de mortalidade pupal e $96,8 \%$ de mortalidade total.

Palavras-chave: Cucumis melo, Azadirachta indica, mosca minadora, manejo integrado de pragas.

Received on October 24, 2017; accepted on April 30, 2018

$\mathrm{T}$ he leafminer Liriomyza sativae (Diptera: Agromyzidae) is one of the most important pests of melon crop (Cucumis melo) in the Brazilian semiarid region in states of Rio Grande do Norte $(\mathrm{RN})$ and Ceará (CE) (Araujo et al., 2013), affecting the main producers and exporters of Brazilian melon (IBGE, 2017). Among damages caused by the leafminer are the reduction of photosynthetic capacity and total soluble solid content of fruits ( $\left.{ }^{\circ} \mathrm{Brix}\right)$, which compromise commercialization of the production (Costa-Lima et al., 2010; Araujo et al., 2013; Costa et al., 2017).

Thus, integrated management strategies to reduce this pest population are essential. Despite the use of different control strategies, such as covering plants with TNT (non woven fabric) during the first 28 days of the crop in the field, and the destruction of crop remains, the leafminer control in the production areas of $\mathrm{RN}$ and $\mathrm{CE}$ depends on synthetic insecticide application
(Guimarães et al., 2009; Lima et al., 2012).

However, few insecticides to control the leafminer in melon crop are registered (Agrofit, 2017), which makes the active principle rotation difficult favoring the selection of resistant populations. Moreover, the consumers look for products cultivated under minimum insecticide sprays and with no residues above the maximum limits (Guimarães et al., 2009). Thus, develop products different from the conventional 
insecticides which can be used in integrated management systems in the melon crop is extremely important.

Among promising alternatives to control the leafminer, insecticides based on vegetable extracts can be relevant, especially neem-based insecticides [Azadirachta indica (Meliaceae)]. Products based on neem, mainly oil from seeds, have been efficient, for different crops and regions in the world, in order to control leafminer larvae species such as Liriomyza huidobrensis (Weintraub \& Horowitz, 1997; Dequech et al., 2010), Liriomyza trifolii (Dimetry et al., 1995; Yildirim \& Baspinar, 2012; Rai et al., 2013) and L. sativae (Hossain \& Poehling, 2006; Hossain et al., 2008; Silva et al., 2015; Silva et al., 2016; Costa et al., 2016).

The main insecticide application method is spraying it directly on leaves. However, this way of application presents the great disadvantage of rapid photodegradation of neem derivatives, which reduces its efficiency, especially when applied in the field (Hossain et al., 2008). Thus, the application of neembased insecticides via irrigation in the soil can be an efficient alternative to control the leafminer fly. Hossain et al. (2008) and Silva et al. (2015) observed significant larval and pupal mortality of $L$. sativae after application, via soil irrigation, of synthetic insecticides based on neem on tomato and melon crops, respectively.

In relation to neem seed aqueous extract, only information of its effect when sprayed directly on larvae of leafminer on melon leaves can be found in literature (Costa et al., 2016). Therefore, the aim of this study was to evaluate the effect of neem seed aqueous extract, applied via soil irrigation, on leafminer larvae of $L$. sativae on melon plants.

\section{MATERIAL AND METHODS}

The experiment was carried out in a greenhouse in Centro de Ciências Agrárias at Universidade Federal Rural do Semi-Árido (UFERSA), Mossoró, Rio Grande do Norte, Brazil. The authors used adults of $L$. sativae, at the age 24 to 72 hours, from Laboratório de Entomologia Aplicada of UFERSA, which follows the methodology recommended by Araujo et al. (2007).

Neem seeds from ripe fruits were used to prepare the aqueous extract, collected in the municipality of Mossoró $\left(5^{\circ} 12^{\prime} 48^{\prime \prime} \mathrm{S} ; 37^{\circ} 18^{\prime} 44^{\prime \prime} \mathrm{W}\right.$, altitude 37 $\mathrm{m})$. Seeds were dried over newspaper, in shade and under $25 \pm 2^{\circ} \mathrm{C}$ temperature in a closed room. After, seeds were crushed to powder in a blender. Doses of extract were evaluated at $1 ; 3 ; 5$ and $10 \mathrm{~g}$ of neem seed powder, added to 100 $\mathrm{mL}$ of distilled water. The mixture was kept at rest for 24 hours in the dark, in order to extract bioactive substances. All mixtures were filtered through void fabric (sterilized) prior to application.

To evaluate the effect of the doses of neem extract on larvae of leafminer, melon plants, cultivar Iracema (yellow type), were cultivated in $500 \mathrm{~mL}$ soil capacity pots, in a greenhouse. When plants presented two developed leaves were taken to the laboratory and submitted to leafminer infestation for 20 minutes in cages $(50 \times 50 \times 50 \mathrm{~cm})$ coated with anti-aphid screen, each cage with an average of 200 couples of leafminer fly (adults at 24 to 72 hours age). Afterwards, plants were transported back to the greenhouse. After 72 hours, the number of larvae per plant was counted and then the treatments via soil irrigation were applied. The extracts were applied manually in a single dose, $50 \mathrm{~mL}$ per plant, with the aid of a millimeter plastic container.

Treatments consisted of distilled water (control) and four doses of neem seed aqueous extract $(1 ; 3 ; 5$ and 10 $\mathrm{g} / 100 \mathrm{~mL}$ ). The experimental design was completely randomized with five treatments (extract with neem seed and control) and 10 replicates (melon plants) per treatment.

Evaluations were divided in two steps. The first was carried out 24 hours after applying the treatments, evaluating the number of dead larvae (larvae without movement) per plant. Larval mortality rate (ML) was calculated using the formula $\% \mathrm{ML}=$ (number of dead larvae / total number of larvae) x 100. In the second step, the pupal mortality was obtained evaluating the larvae which have survived the treatments, registering the number of viable pupae and emerged adults. Pupal mortality rate (MP) was calculated using the formula: $\% \mathrm{MP}=$ (number of emerged adults / number of pupae) $x 100$. The pupae were obtained according to the methodology described by Araujo et al. (2007). The total leafminer mortality rate was evaluated based on the initial number of larvae and number of emerged adults.

Mortality rates were corrected according to the methodology described by Abbott (1925). Obtained data were submitted to analysis of variance, followed by analysis of regression processed by $\mathrm{R}$ statistical software ( $\mathrm{R}$ Development Core team, 2011).

\section{RESULTS AND DISCUSSION}

Increasing the dose of aqueous neem seed extract applied via soil irrigation provided an increase in larval and pupal mortality of the leafminer. Doses of $1 \mathrm{~g} / 100 \mathrm{~mL}$ and $10 \mathrm{~g} / 100$ $\mathrm{mL}$ showed the lowest and the highest larval mortality rate, $6.6 \%$ and $36.4 \%$, respectively (Figure $1 \mathrm{~A}$ ). The three highest doses of neem seed extract caused pupal mortality rates higher than $50 \%$ providing a considerable reduction in the number of emerged adults. The two highest doses, 5 and $10 \mathrm{~g} / 100 \mathrm{~mL}$, resulted in pupal mortality rate of $78.5 \%$ and $96.5 \%$, respectively (Figure $1 \mathrm{~B}$ ). In relation to total mortality, the three highest doses of aqueous neem seed extract provided mortality rate higher than $60 \%$, with the highest dose, 10 $\mathrm{g} / 100 \mathrm{~mL}$, resulting in mortality rate of $96.8 \%$ of the insects (Figure $1 \mathrm{C}$ ).

These results permit to verify the systemic action of aqueous neem seed extract on larval and pupal mortality of the leafminer L. sativae. Systemic action of aqueous neem seed extract in other pest insects, such as Bemisia tabaci (Hemiptera: Aleyrodidae) (Souza \& Vendramim, 2005; Gonçalves \& Bleicher, 2006; Baldin et al., 2007), Tuta absoluta (Lepidoptera: Gelechiidae) (Gonçalves-Gervásio \& Vendramim, 2007) Aphis craccivora (Hemiptera: Aphididae) (Gonçalves \& Bleicher, 2006) had already been reported in 
other studies.

There are also reports of systemic action of commercial products (oils), based on neem, on the mortality of Liriomyza species. Weintraub \& Horowitz (1997) showed mortality rate of $40.3 \%, 48.6 \%$ and $84.4 \%$ of L. huidobrensis larvae applying Neemix $-45^{\circledR}$ (4.5\% azadirachtin), occurring when bean plants (Phaseolus vulgaris) were saturated with 5; 10 and 25 ppm of azadirachtin, respectively. Hossain et al. (2008) verified that an increase in concentration of NeemAzal-U, via soil irrigation on tomato crop, resulted in an increase of larvae mortality rate and reduction of emerged adults of L. sativae. Silva et al. (2015), evaluating Azamax neem oil (12 g/L of azadiractina), applied via soil irrigation on larvae of L. sativae on melon plants, observed increasing rates of larvae mortality and reduction in number of emerged adults with an increased concentration of the product.

Comparing our results to the ones mentioned above, we concluded that aqueous neem seed extract, applied via soil irrigation, was as efficient as the commercial oils for larval and pupal mortality of L. sativae. Some studies show that leafminer mortality is due to the fact that the compounds present in neem, mainly the azadirachtin show insecticidal action mainly through ingestion and can affect the physiological processes of insects, interfering, for example, in regulatory hormones of metamorphosis, which consequently compromises the normal insect development, and may result in mortality (Schmutterer, 1990; Mordue \& Blackwell, 1993; Ascher, 1993; Silva et al., 2009). In relation to insects of order Diptera, such as the leafminer, the effect of neem-based insecticides is variable. Changes occur in larval metamorphosis, larval and pupal mortality of insects after exposed to the products (Schmutterer, 1990; Weintraub \& Horowitz, 1997; Hossain \& Poehling, 2006; Hossain et al., 2008; Silva et al., 2009; Alvarenga et al., 2012; Rai et al., 2013). The fact that the compounds present in neem affect insect physiological processes may explain the increase in larval mortality and, mainly, pupal mortality with an increase in the dose of aqueous neem seed extract.

We observed that aqueous neem seed extract, applied via soil irrigation, resulted in a significant larval and pupal mortality of the leafminer L. sativae on melon, considering that the dose of $10 \mathrm{~g} / 100 \mathrm{~mL}$ is the most efficient. These are the first informations about the application of aqueous neem seed extract via soil irrigation, to control leafminer larvae in the melon leaves. The results are promising, because show that this application method allows the product to kills larvae, causing death. Moreover, aqueous neem extract is easy to be prepared and it is also a low-cost product for producers. However, the authors highlight that further studies under field conditions are necessary to confirm the viability of this technology (the use of aqueous neem seed extract) in the integrated management of melon leafminer.

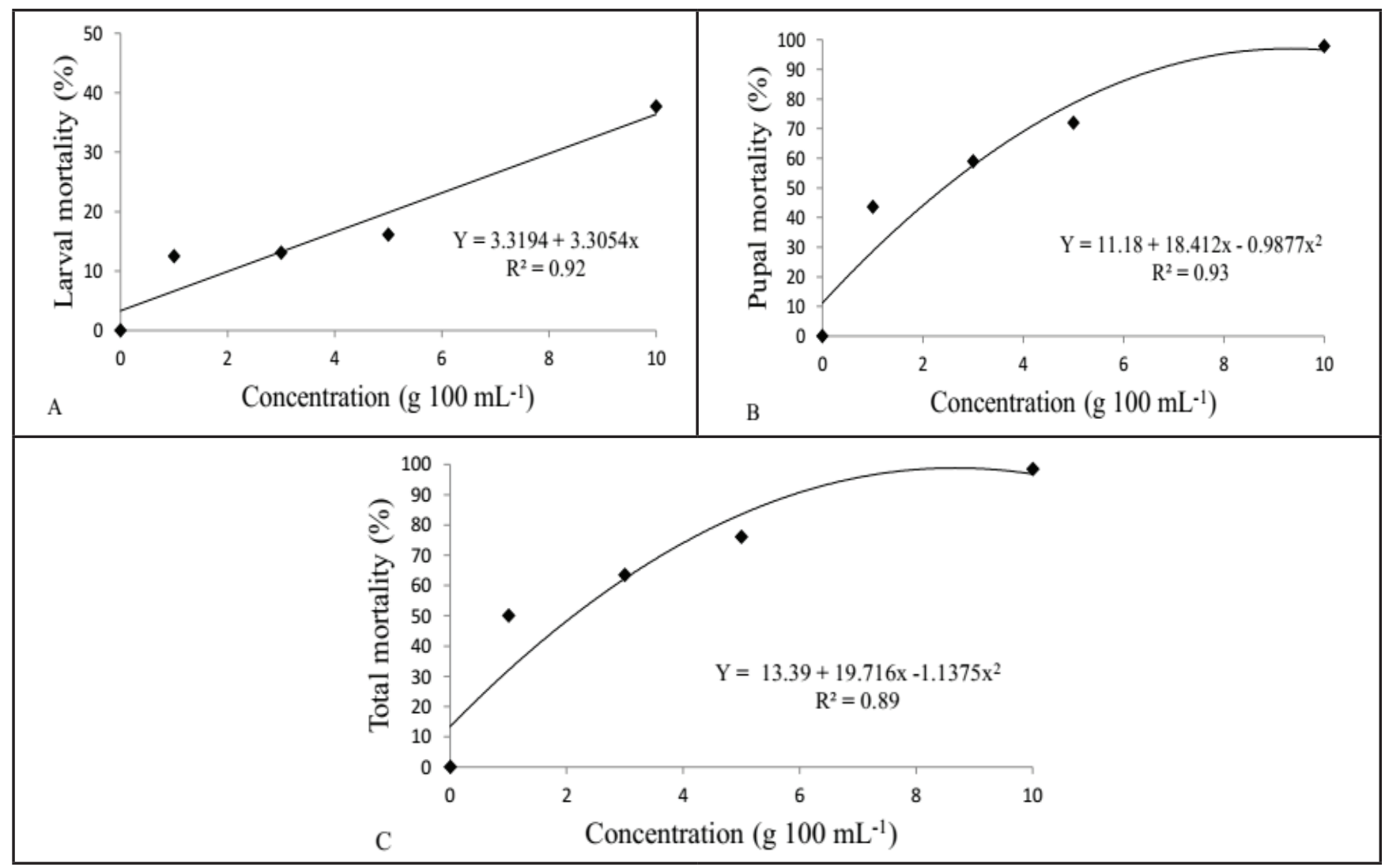

Figure 1. Larval (A), pupal (B) and total (C) mortality rates of Liriomyza sativa through application via soil irrigation, at different doses of aqueous neem seed extract (Azadirachta indica) in melon plants (Cucumis melo). Mossoró, UFERSA, 2017. 


\section{REFERENCES}

ABBOTT, WS. A method of computing the effectiveness of an insecticide. 1925. Journal of Economic Entomology 18: 265-267.

AGROFIT Sistema de Agrotóxicos Fitossanitários. 2017. Available at http://extranet.agricultura. gov.br/agrofit cons/principal agrofit cons de. Accessed August 8, 2017.

ALVARENGA，CD; FRANÇA，WM; GIUSTOLIN, TA; PARANHOS, BAJ; LOPES, GN; CRUZ, PL; BARBOSA, PRR. 2012. Toxicity of neem (Azadirachta indica) seed cake to larvae of the Mediterranean fruit fly, Ceratitis capitata (Diptera: Tephritidae), and its parasitoid, Diachasmimorpha longicaudata (Hymenoptera: Braconidae). Florida Entomologist 95: 57-62.

ARAUJO, EL; PINHEIRO, SAM; GEREMIAS, LD; MENEZES NETTO, AC; MACEDO, LPM. 2007. Técnica de criação da mosca minadora Liriomyza trifolii (Burges) (Diptera: Agromyzidae). Campo Digital 2: 22-26.

ARAUJO, EL; NOGUEIRA, CHF; MENEZES NETTO, AC; BEZERRA, CES. 2013. Biological aspects of the leafminer Liriomyza sativae (Diptera: Agromyzidae) on melon (Cucumis melo L.). Ciência Rural 43: 579-582.

ASCHER, KRS. 1993. Nonconventional insecticidal effects of pesticides available from the neem tree, Azadirachta indica. Archives of Insect Biochemistry and Physiology 22: 433-449.

BALDIN, ELL; SOUZA, DR; SOUZA, ES; BENEDUZZI, RA. 2007. Controle de moscabranca com extratos vegetais, em tomateiro cultivado em casa-de-vegetação. Horticultura Brasileira 25: 602-606.

COSTA-LIMA, TC; GEREMIAS, LD; PARRA, JRP. 2010. Reproductive activity and survivorship of Liriomyza sativae (Diptera: Agromyzidae) at different temperatures and relative humidity levels. Environmental Entomology 39: 195-201.

COSTA, EM; TORRES, SB; FERREIRA, RR; SILVA, FG; ARAUJO, EL. 2016. Extrato aquoso de sementes de nim no controle de Liriomyza sativae (Diptera: Agromyzidae) em meloeiro. Revista Ciência Agronômica 47: 401-406.

COSTA, EM; FREITAS, RMO; SILVA, PAF; ARAUJO, EL. 2017. Determination of damaged leaf area and physiological responses of melon plants submitted to different infestation levels of Liriomyza sativae. Horticultura Brasileira 35: 571-575.

DEQUECH, STB; STURZA, VS; RIBEIRO, LP; SAUSEN, CD; EGEWARTH, R; MILANI, M; SCHIRMANN, J. 2010. Inseticidas botânicos sobre Liriomyza huidobrensis Blanchard (Diptera: Agromyzidae) e seus parasitoides em feijão-de-vagem cultivado em estufa. Biotemas 23: 37-43.

DIMETRY, NZ; BARAKAT, AA; ABDALLA, EF; EL-METWALLY, HE; ABD EL-SALAM, AME. 1995. Evaluation of two neem seed kernel extracts against Liriomyza trifolii (Burg.) (Dip. Agromyzidae). Anzeiger Für Schädlingskunde, Pflanzenschutz, Umweltschutz 68: 39-41.

GONÇALVES, MEC; BLEICHER, E. 2006. Uso de extratos aquosos de nim e azadiractina via sistema radicular para o controle de mosca-branca em meloeiro. Revista Ciência Agronômica 37:182-187.

GONÇALVES, MEC; BLEICHER, E. 2006. Atividade sistêmica de azadiractina e extratos aquosos de sementes de nim sobre o pulgãopreto em feijão-de-corda. Revista Ciência Agronômica 37: 177-181.

G ONÇ A LVE S-GERV Á S IO, R CR; VENDRAMIM, JD. 2007. Bioatividade do extrato aquoso de nim sobre Tuta absoluta (Meyrick, 1917) (Lepidoptera: Gelechiidae) em três formas de aplicação. Ciência e Agrotecnologia 31: 28-34.

GUIMARÃES, JA; MICHEREFF FILHO, M; OLIVEIRA, V; ARAUJO, EL. 2009. Biologia e manejo de mosca minadora no meloeiro. Comunicação Científica Embrapa, 9 p.

HOSSAIN, MB; POEHLING, HM; THÖMING, G; BORGEMEISTER, C. 2008. Effects of soil application of neem $\left(\mathrm{NeemAzal}^{\circledR}{ }_{-} \mathrm{U}\right)$ on different life stages of Liriomyza sativae (Diptera: Agromyzidae) on tomato in the humid tropic. Journal of Plant Diseases and Protection 115: 80-87.

HOSSAIN, MB; POEHLING, HM. 2006. Effects of a neem-based insecticide on different immature life stages of the leafminer Liriomyza sativae on tomato. Phytoparasitica 34: 360-369.

IBGE - Instituto Brasileiro de Geografia e Estatística. 2017. Lavoura temporária. Available at http://www.ibge.gov.br/estadosat/. Accessed August 10, 2017.

LIMA, ACC; COSTA, EM; ARAUJO, EL;
RUGAMA, AJM; GODOY, MS. 2012. Diagnóstico sobre o uso do MIP nas principais áreas produtoras de melão dos Estados do Rio Grande do Norte e Ceará. RevistaAgro@ mbiente On-line 6: 172-178.

MORDUE, AJ; BLACKWELL, A. 1993. Azadirachtin: an update. Journal of Insect Physiology 39: 903-924.

R DEVELOPMENT CORE TEAM. 2011. R: A language and environment for statistical computing. R Foundation for Statistical Computing, Vienna, Austria.ISBN 3-90005107-0. Available at http://www.r-project.org/. Accessed May 5, 2015.

RAI, D; SINGH, AK; SUSHIL, SN; RAI, MK; GUPTA, JP; TYAGI, MP. 2013. Efficacy of insecticides against American serpentine leaf miner, Liriomyza trifolii (Burgess) on tomato crop in N-W region of Uttar Pradesh, India. International Journal of Horticulture 3: 19-21.

SCHMUTTERER, H. 1990. Properties and potential of natural pesticides from the neem tree, Azadiractha indica. Annual Review of Entomology 35: 271-297.

SILVA, AB; BATISTA, JL; BRITO, CH. 2009. Atividade inseticida do nim (Azadiractha indica A. Juss). Revista Verde de Agroecologia e Desenvolvimento Sustentável 4: 7-15.

SILVA, FG; COSTA, EM; FERREIRA, RR; SILVA, FEL; ARAUJO, EL. 2015. Óleo de nim aplicado via irrigação no controle da mosca minadora em meloeiro. Agropecuária Científica no Semi-Árido 11: 122-126.

SILVA, FG; COSTA, EM; FERREIRA, RR; SILVA, FEL; ARAUJO, EL. 2016. Efeito de diferentes concentrações do extrato aquoso de folhas de nim na mortalidade da mosca minadora Liriomyza sativae Blanchard (Diptera: Agromyzidae).RevistaAgro@ mbiente On-Line 10: 381-386.

SOUZA, AP; VENDRAMIM, JD. 2005. Efeito translaminar, sistêmico e de contato de extratos aquosos de sementes de nim sobre Bemisia tabaci (genn.) Biótipo B em tomateiro. Neotropical Entomology 34: 83-87.

WEINTRAUB, PG; HOROWITZ, AR. 1997. Systemic effects of a neem insecticide on Liriomyza huidobrensis larvae. Phytoparasitica 25: 283-289.

YILDIRIM, EM; BASPINAR, H. 2012. Effects of neem on Liriomyza trifolii (Burgess) (Diptera: Agromyzidae) and its parasitoids on tomato greenhouse. Journal of Food, Agriculture \& Environment 10: 381-384. 